\title{
Liver transplantation: a life-saving procedure following amatoxin mushroom poisoning
}

KW Ma1, MB, BS, FHKAM (Surgery), Kenneth SH Chok ${ }^{1,2}$ *, MS, FHKAM (Surgery), CK Chan ${ }^{3}$, MB, BS, FHKAM (Emergency Medicine), WC Dai ${ }^{1}, 2$, MB, BS, FHKAM (Surgery), SL Sin 1 , MB, ChB, FHKAM (Surgery), FL Lau' ${ }^{3}$, MB, BS, FHKAM (Emergency Medicine), SC Chan², MD, FHKAM (Surgery), CM Lo ${ }^{1,2}$, MS, FHKAM (Surgery)

\author{
${ }^{1}$ Department of Surgery, Queen Mary Hospital, Pokfulam, Hong Kong \\ ${ }^{2}$ Department of Surgery, The University of Hong Kong, Pokfulam, Hong Kong \\ ${ }^{3}$ Hong Kong Poison Information Centre, United Christian Hospital, Kwun Tong, Hong Kong
}

*Corresponding author: kennethchok@gmail.com

Hong Kong Med J 2017;23:93-6

DOI: 10.12809/hkmj154616

\section{Case reports}

\section{Case 1}

In April 2013, a 48-year-old man and his wife picked wild mushrooms near Shing Mun Reservoir. After eating the cooked mushrooms, they developed symptoms resembling gastroenteritis and attended accident and emergency department (A\&E) around 12 hours later. The husband was alert with normal blood test results at 18 hours following ingestion. Thirty hours later, his total bilirubin increased to $54 \mu \mathrm{mol} / \mathrm{L}$ (reference range, 4-23 $\mu \mathrm{mol} / \mathrm{L}$ ), serum alanine transaminase (ALT) to $2928 \mathrm{IU} / \mathrm{L}$ (reference range, $8-58 \mathrm{IU} / \mathrm{L}$ ), serum creatinine to $229 \mu \mathrm{mol} / \mathrm{L}$ (reference range, 67-109 $\mu \mathrm{mol} / \mathrm{L}$ ), and international normalised ratio (INR) to 1.56 (reference level, $<1.1$ ). Mushroom poisoning was suspected and the Hong Kong Poison Information Centre was contacted. He was given $\mathrm{N}$-acetylcysteine (NAC), silibinin, and penicillin $\mathrm{G}$ in the intensive care unit. Subsequent blood tests showed no improvement and around 48 hours after ingestion, his serum ALT climbed to $4856 \mathrm{IU} / \mathrm{L}$ and INR to 2.25. He was transferred to the intensive care unit of Queen Mary Hospital (QMH) for further care.

At QMH, computed tomography of the abdomen revealed hypo-enhancement of the liver parenchyma. Liver transplant workup was initiated in view of impending liver failure. Fortunately his liver function started to stabilise 8 hours after admission to QMH, with a serum ALT peak at $3856 \mathrm{IU} / \mathrm{L}$ and INR at 3.5. He then made progressive recovery and was discharged 10 days after admission.

\section{Case 2}

The 47-year-old wife of the patient in case 1 had a high fever of $38.8^{\circ} \mathrm{C}$ upon admission. Blood tests taken around 12 hours after ingestion showed normal results. Twenty-four hours later, her serum ALT rose to $751 \mathrm{IU} / \mathrm{L}$. Thirty-six hours later, it rose further to $2654 \mathrm{IU} / \mathrm{L}$ with an INR of 2.59. A clinical toxicologist was consulted and amatoxin poisoning was diagnosed; NAC, penicillin G, vitamin K, and silibinin were commenced. At 72 hours after ingestion, her serum ALT surged to 5132 IU/L, INR 5.28 , total bilirubin $42 \mu \mathrm{mol} / \mathrm{L}$, and ammonia 35 $\mu \mathrm{mol} / \mathrm{L}$. She was transferred to QMH.

Upon arrival, computed tomographic features were similar to those of her husband, with liver necrosis suggested. Her INR surged further to 7.2. According to the King's College Criteria for acute liver failure, liver transplantation was indicated and transplant workup started. Fortunately, an ABOcompatible deceased donor liver graft was available. Liver transplantation was performed 36 hours after admission (about 5 days after ingestion). The operation took 7 hours, and the patient had $3 \mathrm{~L}$ of blood loss. Pathological examination of the explant showed massive necrosis. She was discharged on postoperative day 30, requiring life-long immunosuppression.

\section{Case 3}

A 29-year-old man ate raw, whitish yellow mushrooms while hiking at Ma On Shan in March 2015. Twelve hours later he developed vomiting and diarrhoea. His symptoms improved afterwards. On day 4 after ingestion, he was found to have jaundice and confusion and was brought to A\&E. Upon arrival, his Glasgow Coma Scale score was 14/15. The first blood tests showed grossly deranged results: serum creatinine $241 \mu \mathrm{mol} / \mathrm{L}$, sodium $117 \mathrm{mmol} / \mathrm{L}$, potassium $6.1 \mathrm{mmol} / \mathrm{L}$, total bilirubin $246 \mu \mathrm{mol} / \mathrm{L}$, serum ALT $9390 \mathrm{IU} / \mathrm{L}$, and INR >8. Before he was transferred to QMH, NAC, penicillin G, vitamin K1, and fresh frozen plasma were given.

At $\mathrm{QMH}$, liver transplant workup was started, but his elder brother was not accepted for liver donation as he was shown to have severe fatty liver on computed tomography. The patient's condition deteriorated. His Glasgow Coma Scale score dropped to $4 / 15$, and oxygen desaturation and seizure developed. With the presence of severe hepatic encephalopathy, any delay in rescue would 
increase the chance of irreversible brain insult due to cerebral oedema. Coincidentally, a liver from a 60 -year-old brain-dead woman whose blood group was identical to the patient's was available.

A multidisciplinary clinical team involving cardiac and respiratory physicians, radiologists, anaesthesiologists, intensivists, cardiothoracic surgeons, and liver transplant surgeons coordinated to expedite the operation. Liver procurement and implantation were started within a few hours, with two teams of liver transplant surgeons working in parallel. The recipient operation took 6 hours. Pathological examination of the explant showed confluent necrosis. The patient was discharged on day 20 .

\section{Discussion}

According to the Hong Kong Poison Information Centre database, there have been seven documented cases of amatoxin mushroom poisoning since July 2005, resulting in one death and two liver transplantations (Table). Amatoxin poisoning leads to the most serious consequences and accounts for more than $90 \%$ of mushroom-related mortalities. ${ }^{1}$ Amatoxins, phallotoxins, and other toxic cyclopeptides are produced by certain mushroom species of three genera, namely the Amanita, Galerina, and Lepiota, while Amanita phalloides is the most infamous type, also known as the "death cap". Amatoxins are highly toxic and cannot be

TABLE. Summary of all amatoxin mushroom poisoning cases in Hong Kong in the past 10 years from the database of Hong Kong Poison Information Centre

\begin{tabular}{|c|c|c|c|c|}
\hline $\begin{array}{l}\text { Case } \\
\text { No. }\end{array}$ & $\begin{array}{c}\text { Sex/age } \\
\text { (years) }\end{array}$ & Clinical presentation & Source of mushroom & Investigation, treatment, and outcome \\
\hline 1 & $M / 48$ & $\begin{array}{l}\text { Vomiting and diarrhoea started } 12 \text { hours after } \\
\text { mushroom ingestion }\end{array}$ & $\begin{array}{l}\text { Self-picked near Shing } \\
\text { Mun Reservoir, Hong } \\
\text { Kong }\end{array}$ & $\begin{array}{l}\text { - Deranged liver and renal functions } \\
\text { - Presence of amatoxins and phallacidin in the urine } \\
\text { - NAC, MDAC, high-dose penicillin, and silibinin given } \\
\text { - Liver function, coagulation profile, and blood } \\
\text { ammonia showed improvement after day } 4 \\
\text { - Discharged with full recovery }\end{array}$ \\
\hline 2 & $\mathrm{~F} / 47$ & $\begin{array}{l}\text { Wife of case } 1 . \text { Vomiting and diarrhoea started } \\
12 \text { hours after mushroom ingestion }\end{array}$ & Same as case 1 & $\begin{array}{l}\text { - Progressively deranged liver function } \\
\text { - Presence of amatoxins and phallacidin in the urine } \\
\text { (Amanita farinosa was identified in mushroom sample) } \\
\text { - NAC, MDAC, high-dose penicillin, and silibinin given } \\
\text { - DDLT performed on day } 5 \\
\text { - Discharged on postoperative day } 30 \text {, requiring life- } \\
\text { long immunosuppression }\end{array}$ \\
\hline 3 & $M / 29$ & $\begin{array}{l}\text { Gastroenteritic symptoms appeared } 12 \\
\text { hours after mushroom ingestion. Confusion, } \\
\text { jaundice on day } 5 \text {, and attended A\&E }\end{array}$ & $\begin{array}{l}\text { Self-picked near Ma } \\
\text { On Shan, Hong Kong }\end{array}$ & $\begin{array}{l}\text { - Fulminant liver failure with rapidly deteriorating } \\
\text { hepatic encephalopathy, together with hepatorenal } \\
\text { syndrome upon admission } \\
\text { - Absence of amatoxins and phallacidin in the urine } \\
\text { - NAC, penicillin, and silibinin given } \\
\text { - DDLT performed on day } 2 \\
\text { - Discharged on postoperative day } 20\end{array}$ \\
\hline 4 & $\mathrm{~F} / 43$ & $\begin{array}{l}\text { Severe vomiting and diarrhoea started } 12 \\
\text { hours after mushroom ingestion. Attended } \\
\text { hospital in Hong Kong on day } 5 \text { with jaundice, } \\
\text { confusion, tachycardia, and hypotension }\end{array}$ & $\begin{array}{l}\text { Self-picked and } \\
\text { consumed in South } \\
\text { Africa }\end{array}$ & $\begin{array}{l}\text { - Deranged liver and renal functions, metabolic acidosis } \\
\text { - Presence of phallacidin in the urine } \\
\text { - Supportive treatment, died } 1 \text { day after admission }\end{array}$ \\
\hline 5 & $M / 44$ & $\begin{array}{l}\text { Husband of case } 4 \text {. Vomiting and diarrhoea } \\
\text { started } 12 \text { hours after mushroom ingestion. } \\
\text { Presented to A\&E with resolving symptoms on } \\
\text { day } 5 \text { after wife's death }\end{array}$ & Same as case 4 & $\begin{array}{l}\text { - Deranged liver function } \\
\text { - Absence of amatoxins and phallacidin in the urine } \\
\text { - NAC and MDAC given } \\
\text { - Discharged on day } 7 \text { with improving liver function and } \\
\text { resolution of symptoms } \\
\text { - Lost to subsequent follow-up }\end{array}$ \\
\hline 6 & $\mathrm{M} / 74$ & $\begin{array}{l}\text { Vomiting and diarrhoea started } 9 \text { hours after } \\
\text { mushroom ingestion. Attended A\&E on day } 1\end{array}$ & $\begin{array}{l}\text { Self-picked near Tai } \\
\text { Mo Shan in Hong } \\
\text { Kong }\end{array}$ & $\begin{array}{l}\text { - Deranged liver and renal functions } \\
\text { - Presence of amatoxins and phallacidin in the urine } \\
\text { - NAC, MDAC, high-dose penicillin, and silibinin given } \\
\text { - Liver function improved after day } 4 \\
\text { - Discharged after } 5 \text { weeks with full recovery }\end{array}$ \\
\hline 7 & $\mathrm{~F} / 40$ & $\begin{array}{l}\text { Vomiting and diarrhoea started } 8 \text { hours after } \\
\text { mushroom ingestion. Attended hospital in } \\
\text { Hong Kong on day } 4 \text { with mild dehydration } \\
\text { and persistent symptoms }\end{array}$ & $\begin{array}{l}\text { Self-picked and } \\
\text { consumed in Ningxia, } \\
\text { China }\end{array}$ & $\begin{array}{l}\text { - Deranged liver and renal functions } \\
\text { - Presence of phallacidin in the urine } \\
\text { - NAC, MDAC, high-dose penicillin, and silibinin given } \\
\text { - Liver function improved after admission } \\
\text { - Discharged on day } 5 \\
\text { - Lost to subsequent follow-up }\end{array}$ \\
\hline
\end{tabular}

Abbreviations: A\&E = accident and emergency department; DDLT = deceased donor liver transplantation; MDAC = multiple-dose activated charcoal; $\mathrm{NAC}=\mathrm{N}$-acetylcysteine 
destroyed by any means of food processing. ${ }^{3}$ The liver is the most affected organ, as amatoxins are absorbed preferentially by hepatocytes and go through the enterohepatic circulation. Other organs can also be intoxicated. If the kidneys are involved, acute renal failure secondary to acute tubular necrosis may result. ${ }^{2}$

The clinical manifestation of amatoxin poisoning typically consists of four sequential phases. In the first phase, the 'lag phase', the patient remains asymptomatic for at least 6 hours after ingestion. ${ }^{4}$ This is one of the distinguishing features of amatoxin poisoning, as most benign mushroom poisonings cause gastrointestinal symptoms within 4 hours of ingestion. The 'gastrointestinal phase' comes next, starting at 6 to 24 hours after ingestion, with symptoms resembling severe gastroenteritis. Blood tests in this phase usually show normal results unless there is significant fluid loss via the gastrointestinal tract. ${ }^{5-9}$ The 'apparent convalescence phase' follows at 36 to 48 hours after ingestion. In this period, the patient has some relief from gastrointestinal symptoms, but at the same time amatoxins start to cause discernible hepatic injury presenting as jaundice and a rise in serum aminotransferase. Finally, the 'acute liver failure phase' sets in, with drastic surges in liver enzymes, renal failure, encephalopathy, hepatorenal syndrome ${ }^{10}$ and multiorgan failure. Without liver transplantation, severe cases end in mortality 1 to 2 weeks after ingestion. ${ }^{11}$ Recovery with supportive treatment is possible in cases of mild intoxication.

Tests including radioimmunoassay, enzymelinked immunosorbent assay, and high-performance liquid chromatography are used to detect amatoxins in body fluids or liver explants or as part of an autopsy for confirmation. The sensitivity of these tests depends on the time of sample collection. The detection window of amatoxins is up to 5 days after ingestion in urine and up to 22 days in tissue. ${ }^{12}$ Residual mushroom sample can be used for mycological assessment. Urine amatoxin testing was performed in the three cases reported above. Cases 1 and 2 had positive results, whereas the result in case 3 was negative, apparently because the patient was brought to clinical attention several days after ingestion; the negative result did not exclude amatoxin poisoning. Diagnosis of amatoxin poisoning requires a high index of suspicion and detailed history taking, with particular attention to the sequencing of events.

Management of amatoxin poisoning can be classified as supportive with specific treatments. The survival chance is $70 \%$ to $100 \%$ with early diagnosis and intensive care. ${ }^{4}$ Patients who suffer from severe gastrointestinal symptoms or organ failure require intensive care aiming at an hourly urine output of 100 to $200 \mathrm{~mL} .{ }^{4}$ Significant coagulopathy must be corrected. Specific treatment can be subclassified into medical and surgical one. N-acetylcysteine, silibinin, penicillin G, multiple-dose activated charcoal, and enhanced elimination methods constitute the mainstay of medical treatment. ${ }^{4-7,9}$ $\mathrm{N}$-acetylcysteine protects the liver by being an oxygen free radical scavenger, while silibinin works by inhibiting the organic anion transmembrane transporter responsible for the uptake of amatoxins by hepatocytes and the enterohepatic recycling of these toxins. ${ }^{4}$ The role of penicillin $\mathrm{G}$ in treating amatoxin poisoning is controversial. Penicillin G blocks uptake of amatoxins by hepatocytes and binds to circulating amatoxins. Oral multiple-dose activated charcoal can be administered within 3 days of ingestion. It works by inhibiting amatoxin absorption through the intestinal mucosa and reabsorption via the enterohepatic circulation. Enhanced elimination methods including extracorporeal albumin dialysis, the molecular adsorbent recirculating system, and the fractionated plasma separation and adsorption system (the Prometheus System) are investigational therapies for amatoxin poisoning.

Conventional therapies fail in $10 \%$ to $20 \%$ of cases. ${ }^{6}$ Death resulting from fulminant liver failure is inevitable if timely liver transplantation is not performed. As to when liver transplantation is needed, there are different sets of parameters in use, but none has gained universal acceptance in the context of amatoxin-related liver failure. At QMH, the King's College Criteria are adopted. Pathological examination suggested irreversible liver damage in the explants in cases 2 and 3, and justified our decision regarding transplantation.

Amatoxin poisoning is lethal. Clinicians should be aware of its natural history and start treatment early. Transferal, if needed, has to be timely. Public education about the dangers of wild mushroom consumption is vital.

\section{Acknowledgements}

We would like to thank Dr James YY Fung, Consultant Hepatologist at Queen Mary Hospital, for his expert advice on managing the above patients. We also thank Dr SH Tsui for providing patient data for this case report.

\section{References}

1. Bryngil J. Amanita phalloides. Clin Toxicol Rev 1999;21:191-8.

2. Himmelmann A, Mang G, Schnorf-Huber S. Lethal ingestion of stored Amanita phalloides mushrooms. Swiss Med Wkly 2001;131:616-7.

3. Gibbons RB. Mushroom poisoning. Compr Ther 1982;8:339.

4. Goldfrank LR. Mushrooms. In: Hoffman RS, Howland MA, Lewin NA, Nelson LS, Goldfrank LR, editors. Goldfrank's toxicologic emergencies. 10th ed. New York: McGraw-Hill; 
2015: 1500-14.

5. Enjalbert F, Rapior S, Nouguier-Soulé J, Guillon S, Amouroux N, Cabot $\mathrm{C}$. Treatment of amatoxin poisoning: 20-year retrospective analysis. J Toxicol Clin Toxicol 2002;40:715-57.

6. Broussard CN, Aggarwal A, Lacey SR, et al. Mushroom poisoning-from diarrhea to liver transplantation. Am J Gastroenterol 2001;96:3195-8.

7. Berger KL, Guss DA. Mycotoxins revisited: part I. J Emerg Med 2005;28:53-62.

8. Leist M, Gantner F, Naumann H, et al. Tumor necrosis factor-induced apoptosis during the poisoning of mice with hepatotoxins. Gastroenterology 1997;112:923-34.

9. Paaso B, Harrison DC. A new look at an old problem: mushroom poisoning. Clinical presentations and new therapeutic approaches. Am J Med 1975;58:5059.

10. Sanz P, Reig R, Borrás L, Martínez J, Máñez R, Corbella J. Disseminated intravascular coagulation and mesenteric venous thrombosis in fatal amanita poisoning. Hum Toxicol 1988;7:199-201.

11. Butera R, Locatelli C, Coccini T, Manzo L. Diagnostic accuracy of urinary amanitin in suspected mushroom poisoning: a pilot study. J Toxicol Clin Toxicol 2004;42:90112.

12. Jaeger A, Jehl F, Flesch F, Sauder P, Kopferschmitt J. Kinetics of amatoxins in human poisoning: therapeutic implications. J Toxicol Clin Toxicol 1993;31:63-80. 